\title{
Feed Conditions Preference for type Ant (Oecophyla smaragdina) In Morphometric Swiftlet (Aerodramus fuciphagus)
}

\author{
Sunu Kuntjoro ${ }^{1}$, Fida Rachmadiarti ${ }^{2}$, Herlina Fitri Hidajati ${ }^{3}$ \\ \{sunukuntjoro@unesa.ac.id ${ }^{1}$ \} \\ Universitas Negeri Surabaya, Surabaya, Jawa Timur $60213^{1,2,3}$
}

\begin{abstract}
Swiftlet bird is a type of bird that produces a product in the form of a nest made from saliva. The aim of this study was to determine the morphometric differences in swiftlets with different feed conditions of the ant species (Oecophyla smaragdina) to the weight gain, length and length of the tail and wings of the swiftlet bird (Aerodramus fuchipaghus) and to find the most optimal feed conditions of the ant species (Oecophyla smaragdina) for the growth of swiftlet birds. The results obtained morphometric differences in the administration of different types of ant. Furthermore, the optimal growth of swiftlet was in ant species in the form of white ants with an average growth of 0.282 gr/day (weight), $0.244 \mathrm{~cm} /$ day (wing length), $0.122 \mathrm{~cm} /$ day (tail length) and $0.170 \mathrm{~cm} /$ day (body length). The most optimal feed conditions of ant species for the growth of swiftlet bird was white ant (Oecophyla smaragdina).
\end{abstract}

Keywords: swiftlet bird (Aerodramus fuchipaghus), ant (Oecophyla smaragdina)

\section{Introduction}

One type of bird that produces economic value products is a swiftlet bird. Swiftlet bird is a type of bird that produces a product in the form of a nest made from saliva. $80 \%$ of the largest swiftlet bird nest products from various parts of the world are produced from Indonesia. In addition, Indonesia is a swiftlet bird-producing country with a production of around 400 tons per year. Indonesian swiftlet bird's nest products are exported to various countries such as Hong Kong, China, Taiwan, Korea, Japan, Singapore, and Malaysia.

White nest swiftlet bird is a type of swiftlet bird that is widely bred in Indonesia because it has advantages including an easy cultivation system, high economic value, and the most popular white swiftlet birds nest production. This is the reason for the white nest swiftlet bird to do research on white swiftlet bird feeding. The feed is needed for survival, growth, forming new cells and reproduction. For that reason, at the stage of growth, swiftlet birds require high nutritional content in the form of protein, phosphorus, carbohydrates, fats and several other nutrients. High nutrient content can affect weight gain, height and growth of hair and other organs [1].

Tarburton [2] conducted a study on the study of the feeding behavior of white nest swiftlet birds from hatching to flight. The study tried to find information on the behavior of swiftlet bird juvenile when feeding using ant feed, crickets, and chicken feed. The results of this study are the presence of hunger signs can be known by the behavior and sound issued by 
swiftlet birds that sound loud squeaking, sticking out his head and opening his mouth wide. This sign of hunger is influenced by the signal due to the body of a swiftlet bird need energy in the form of protein nutrition because muscle is a storage place of protein so that if you feel hungry there will be a reduction in muscle volume due to the need for protein obtained from feed.

Ant is a type of feed that is widely used for bird feed because it is easily available and has a high protein content. In addition, various studies of swiftlet bird feeding using ant are mostly done but are limited to studies of feeding behavior, survival rates, and growth based on weight gain. The problem of the decline in the level of endurance of the swiftlet bird is due to the suboptimal type of feed so that the nutrient content during the growth of the swiftlet bird is not available so that the production of nests is also not good. For this reason, research on swiftlet bird feeding as a method of breeding swiftlet bird so that high growth can increase swiftlet birds nest productivity. In this study, the type of feed used is ant due to its high protein content and is easily available for bird feed in general.

The purpose of this research is knowing the morphometric differences in swiftlets with different conditions of the ant species (Oecophyla smaragdina) to increase the weight, length, and length of the tail and wings of the swift (Aerodramus fuchipaghus) and looking for the most optimal feed conditions of ant species for the growth of swiftlet bird.

\section{Material and Methods}

This type of research is experimental because there are research variables in the form of manipulation variables, response variables and control variables with treatment and repetition. This research was carried out at birdhouse Sidayu, Gresik, East Java

Control variables: Feeding is carried out 4 times a day with a fixed time schedule that is at 07.00-08.00 (morning), 11.00-12.00 (afternoon), 16.00-17.00 (afternoon), and 19.00-20.00 (night); feeding dose ( $30 \%$ of body weight) in each treatment; the age of the swiftlet as well as humidity and room temperature. Variable manipulation: feed conditions in the form of different forms of ants (Oecophyla smaragdina). Response variable: swiftlet bird growth is measured by weight gain, body length increase, tail length increase, and wing length.

The feed given to swiftlet birds in the form of ant (Oecophyla smaragdina) which is obtained from bird feed sellers is cleaned of dirt and litter. Then ant is sorted and separated the egg-shaped and the young ant-shaped. Then, the young ant is boiled for 15 minutes to kill parasitic microorganisms such as bacteria.

Weight and body measurements of swiftlet birds were performed before and after treatment. On days $1,7,14,21,28,35$, and 45 were calculated - average weight and height. Measurement of body length increase observation of Aerodramus fuchipaghus body length measurements was measured from the end of the beak to the tip of the tail feathers (Duryadi et al., 2013). Measurement of body length is done by measuring individual birds with a metal bar with an accuracy of $1 \mathrm{~mm}$. Height increase was measured from the tip of the scapula to the longest tip of the primary wing feathers without emphasis. Measurement of tail length increase was measured between the base of the tail feathers to the longest tail feather tip [3 - 6].

\section{Result and Discussion}

\subsection{Growth of Swiftlet bird Weight}


The highest average weight gain in swiftlet birds was reached 0.282 grams/day by treating the feed using white ant feed. While the lowest average growth of 0.256 grams/day by treating the feed using ant eggs. In the treatment of feeding with ant eggs, there are 5 bird swiftlet birds died and only 1 can survive. The death occurred before day $7^{\text {th }}$ of 3 birds and 2 birds before day 14th as shown on Table 1.

Table 1. Weight comparison with different types of feed.

\begin{tabular}{|c|c|c|c|c|c|c|c|c|c|}
\hline \multirow{2}{*}{$\begin{array}{l}\text { Treat } \\
\text { ment }\end{array}$} & \multicolumn{6}{|c|}{ Weight (gram) / Day } & \multirow{2}{*}{\multicolumn{2}{|c|}{ erage }} & \multirow[t]{2}{*}{ Note } \\
\hline & & 1 & $\mathrm{~h}$ & & th & th & & & \\
\hline & 1.58 & 5.28 & 8.35 & 10.37 & 11.44 & 12.77 & 13.12 & 0,256 & 5 dead and 1 alive \\
\hline ? & 1.56 & 5.26 & 9.76 & 11.36 & 12.53 & 13.90 & 14.26 & 0.282 & 6 lived \\
\hline ; & 1.57 & 5.26 & 9.76 & 11.36 & 12.26 & 13.61 & 14.16 & 0.279 & 2 dead and 4 alive \\
\hline
\end{tabular}

The treatment of feeding with white ants did not occur at all birds died whereas the treatment of egg white and ant mixed feeds there were 2 bird deaths which occurred 1 bird before the 7th day and 1 bird before the 14th day as can be seen on Figure 1.

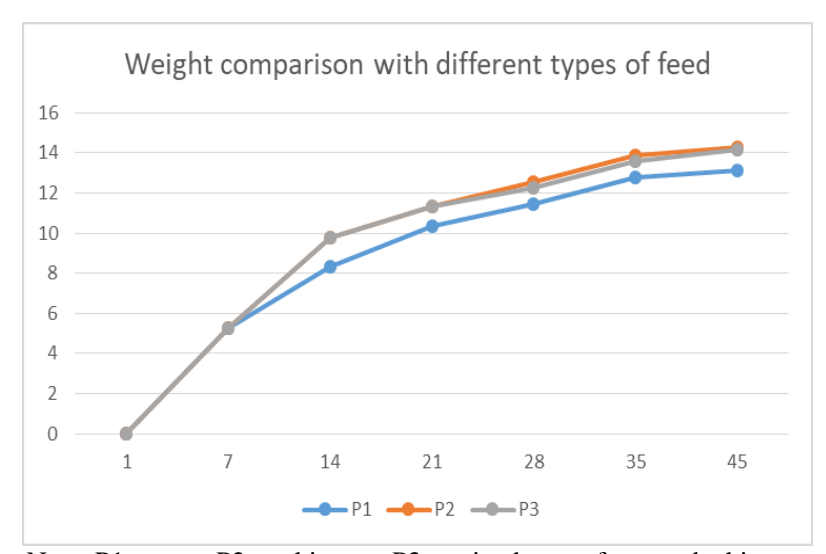

Note: $\mathrm{P} 1$ = egg; $\mathrm{P} 2$ = white ant; $\mathrm{P} 3$ = mixed type of egg and white ant

Fig. 1. Weight comparison with different types of feed.

\subsection{Growth of Swiftlet Wing Length}

The difference in the growth of the swiftlet bird's wing length can be known from the results of different feeding treatments, with the highest wing length growth at $0.244 \mathrm{~cm} /$ day indicated by white ant feeding. While the lowest wing length growth of $0.216 \mathrm{~cm} /$ day in the treatment of feeding with ant eggs. Although there was no difference, in the treatment of feeding with ant eggs there were 5 bird deaths while the feeding of white ants did not occur shown on Table 2 and Figure 2.

\subsection{Growth of Swiftlet Tail Length}

The growth of the tail length at the beginning of the hatching of the three treatments did not have tail feathers on all the birds until the 7th day had appeared needle-shaped tail feathers. There is a similarity in the growth of the average length of the swiftlet bird's tail by $0.122 \mathrm{~cm} / \mathrm{day}$ 
in the treatment of feeding white ants and mixed feeds. While the treatment of ant eggs feed the growth of the tail length of $0.106 \mathrm{~cm} /$ day as shown on Table 3 and Figure 3.

Table 2. Comparison of wing lengths with different types of feed.

\begin{tabular}{cccccccccc}
\hline $\begin{array}{c}\text { Treat } \\
\text { ment }\end{array}$ & 1st & 7nd & 14th & 21st & 28th & 35th & 45th & Average & (gram) \\
\hline P1 & 0.55 & 2.47 & 2.80 & 5.80 & 7.40 & 9.70 & 10.30 & 0.216 & 5 dead and 1 alive \\
P2 & 0.52 & 2.65 & 3.52 & 6.78 & 8.72 & 10.52 & 11.50 & 0.244 & 6 lived \\
P3 & 0.55 & 2.58 & 3.53 & 6.33 & 8.28 & 10.38 & 11.50 & 0.243 & 2 dead and 4 alive \\
\hline
\end{tabular}

Note: P1 = egg; P2 = white ant; P3 = mixed type of egg and white ant

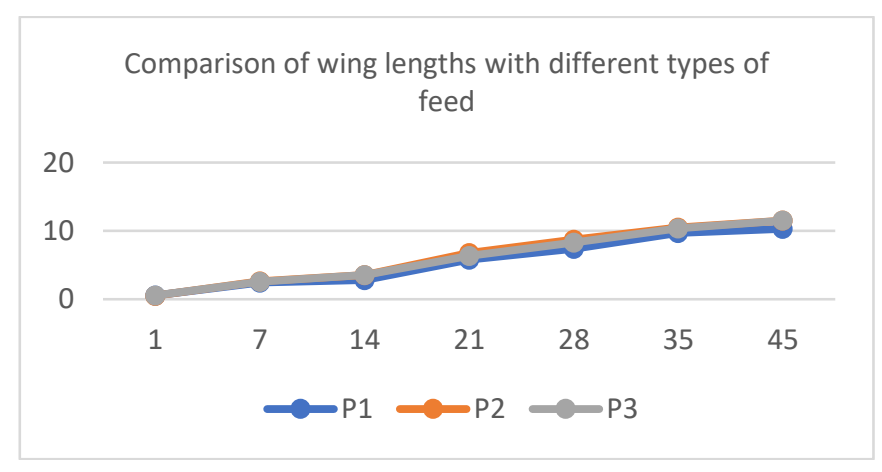

Note: $\mathrm{P} 1$ = egg; $\mathrm{P} 2$ = white ant; $\mathrm{P} 3$ = mixed type of egg and white ant

Fig. 2. Wing length comparison with different types of feed.

Table 3. Comparison of Tail length with different types of feed.

\begin{tabular}{cccccccccc}
\hline $\begin{array}{c}\text { Treat } \\
\text { ment }\end{array}$ & 1st & 7nd & 14th & 21st & 28th & 35th & 45th & Average & (gram) \\
\hline P1 & 0 & 0.03 & 2.80 & 1.50 & 2.50 & 3.60 & 4.80 & 0.106 & 5 dead and 1 alive \\
P2 & 0 & 0.15 & 3.52 & 2.78 & 3.72 & 4.52 & 5.50 & 0.122 & 6 lived \\
P3 & 0 & 0.08 & 3.53 & 2.33 & 3.28 & 4.38 & 5.50 & 0.122 & 2 dead and 4 alive \\
\hline Note: P1 = egg; P2 = white ant; P3 = mixed type of egg and white ant
\end{tabular}

\subsection{Growth of Swiftlet Body Length}

Growth of swiftlet bird's body length by treatment of ant egg feeding begins after hatching with a body length of $2.55 \mathrm{~cm}$ and after 45 days it becomes $9.40 \mathrm{~cm}$ with an average growth of $0.152 \mathrm{~cm} /$ day and the highest mortality of 5 birds. While the growth of the body length of swifts with ants feeding treatment begins from after hatching with a body length of $2.52 \mathrm{~cm}$ to 10.20 $\mathrm{cm}$ with an average growth of $0.170 \mathrm{~cm} /$ day and no bird mortality as shown on Table 4 and Figure 4 . 


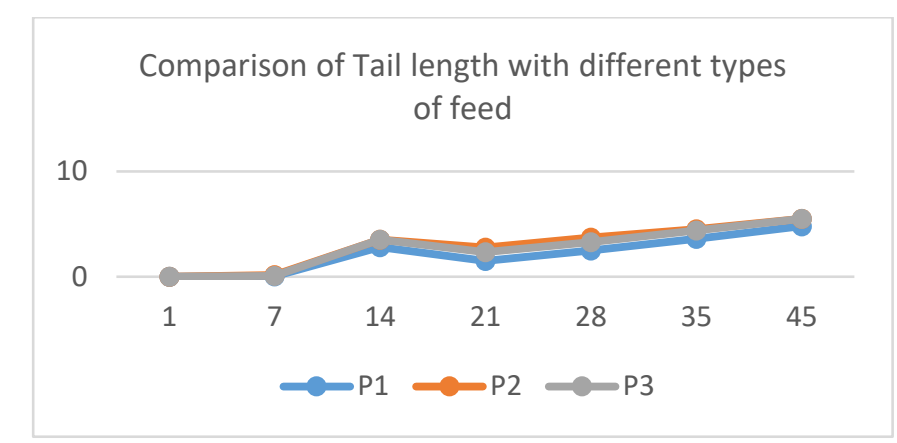

Note: P1 = egg; P2 = white ant; P3 = mixed type of egg and white ant

Fig. 3. Tail length comparison with different types of feed.

Table 4. Comparison of body length with different types of feed.

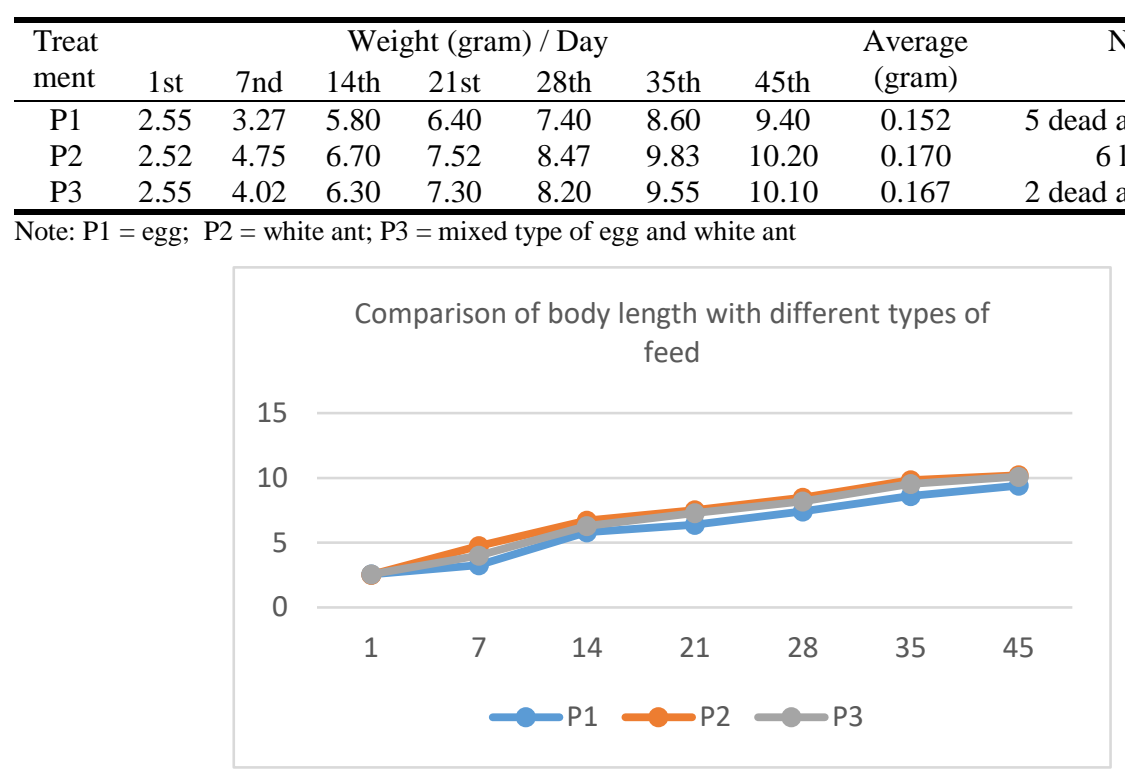

Note: P1 = egg; P2 = white ant; P3 = mixed type of egg and white ant

Fig. 4. Body length comparison with different types of feed.

Based on the results of measurements with 3 different feeding treatments, we get the results that feeding with white ants will grow faster in body weight, wing length, tail length and body length of swiftlet birds. In addition, the highest mortality of 5 birds was in the treatment of ant egg feeding. This is because ant eggs have a very strong layer to protect the ant eggs from ant eggs damage. Ant eggs can be encased in two membranes, namely the vitelline membrane which is an egg cell membrane and chorion or eggshell. The chorion functions like a cuticle that protects against physical disturbance, evaporation of water, and also for ventilation (breathing) of the egg. 
Insects are the most diverse group of animals on earth. They inhabit nearly all terrestrial habitats. One of the factors underlying this success is the ability of insect eggs to survive in adverse conditions. For a long time, the ability to survive these adverse conditions has been attributed to maternal investment in the form of a protective eggshell. Most of the largest part of the egg is filled with egg yolk (yolk) or deutoplasma (deutoplasm), cytoplasm and nucleus only occupy a small part of the egg. The yolk contains carbohydrates, proteins, and lipids. Protein is the most part. The cytoplasm is around the nucleus (cytoplasm of the nucleus) and around the edge of the yolk (periplasm or cytoplasm cortex = cortical cytoplasm)

\section{Conclusion}

The most optimal feed conditions of ant species for the growth of swiftlet bird was white ant (Oecophyla smaragdina)

Acknowledgment. The author would like to thank Fatich Marzuki who allow me to use his swiftlet bird farm.

\section{References}

[1] McCay, C. M., Crowell, M. F., \& Maynard, L. A.: The effect of retarded growth upon the length of life span and upon the ultimate body size: one figure. The journal of Nutrition, 10(1), 63-79 (1935)

[2] Tarburton, M. K. (1988). Breeding biology of the White-rumped Swiftlet at Chillagoe. Emu, 88(4), 202-209.

[3] Møller, A. P.: Development of fluctuating asymmetry in tail feathers of the barn swallow Hirundo rustica. Journal of evolutionary Biology, 9(6), 677-694 (1996)

[4] Evans, M. R., \& Thomas, A. L. The aerodynamic and mechanical effects of elongated tails in the scarlet-tufted malachite sunbird: measuring the cost of a handicap. Animal Behaviour, 43(2), 337-347 (1992)

[5] Del Hoyo, J., Del Hoyo, J., Elliott, A., \& Sargatal, J.: Handbook of the birds of the world (Vol. 1, No. 8). Barcelona: Lynx edicions (1992)

[6] Kang, N., Hails, C. J., \& Sigurdsson, J. B.: Nest construction and egg-laying in Edible-nest Swiftlets Aerodramus spp. and the implications for harvesting. Ibis, 133(2), 170-177 (1991) 